TP Periodica Polytechnica Chemical Engineering

61(2), pp. 144-148, 2017

https://doi.org/10.3311/PPch.8895

Creative Commons Attribution (i)

RESEARCH ARTICLE

\section{Synthesis of Solketal from Glycerol and Acetone over Amberlyst-46 to Produce an Oxygenated Fuel Additive}

\author{
Oguzhan Ilgen $^{1 *}$, Senol Yerlikaya ${ }^{2}$, Funda Oguzkaya Akyurek ${ }^{2}$
}

Received 10 December 2015; accepted after revision 03 April 2016

\begin{abstract}
Recently, with rapid consumption of fossil fuel sources all over the world, the interest in alternative fuels has increased. Biodiesel is one of the most preferable one produced by transesterification of triglyceride with alcohol, yielding glycerol as the by-product. As a drawback, increase in biodiesel production has lead to an increase in availability of glycerol. In this work, glycerol was converted to solketal in $84 \%$ chemical yield under optimum conditions via reaction of acetone over Amberlyst-46 heterogeneous catalyst. Solketal was blended 3, 5, 7 and 10 vol\% with oxygenate free gasoline. When compared to unblended gasoline the higher values of research octane number and motor octane number were obtained with blended ones.
\end{abstract}

\section{Keywords}

Solketal, acetone, glycerol, Amberlyst-46, heterogeneous catalyst

\footnotetext{
${ }^{1}$ Department of Chemical Engineering,

Faculty of Engineering, Kocaeli University,

Umuttepe, 41380, İzmit-Kocaeli, Turkey

${ }^{2}$ TUBITAK Marmara Research Center, Energy Institute,

41470, Gebze, Kocaeli, Turkey

*Corresponding author, email: oilgen@kocaeli.edu.tr
}

\section{Introduction}

Both global warming and decrease in fossil fuel sources are the basic causes of searching for alternative fuels [1]. Biofuels are considered to be an attractive alternative to fossil fuels due to their environmental and renewable nature [2]. As biodiesel consists of very low sulfur and has low toxicity, leading to the emission of green house gases during combustion, it has been accepted as the "future fuel" $[3,4]$. Therefore, the European Union has proposed to blend diesel with biodiesel by $10 \%$ in the transportation industry by the end of 2020, which gives rise to 17.4 million tons of biodiesel production per year [5]. Transesterification of vegetable oils or animal fat with alcohol generally methanol or ethanol over basic catalysts affords biodiesel and glycerol is to be formed as a by-product of biodiesel production by $10 \mathrm{wt} \%[6,7]$. By 2020, it is predicted that global glycerol formation will be 41.9 billion liters [8]. Corresponding glycerol cannot be used for food and pharmaceutical industries because of its high contamination of methanol [9]. Furthermore, its high boiling polar triol property prevents to utilize it directly as a fuel additive. Hence, transformation of glycerol into valuable chemicals via various catalytic process involving oxidation, dehydration, hydrogenation, etherification and esterification has received much attention in recent years [1013]. Apart from the glycerol, acetone which is the other feedstock for solketal production, is commercially obtained from petrochemical processes. However, acetone is also produced from the non-petroleum feedstock such as acetone-butanolethanol (ABE) fermentation process. Specifically, the condensation of glycerol to yield ketals and acetals has been offered as fuel additives [14]. Solketal which is synthesized from the ketalization reaction of acetone and glycerol can be used as a fuel additive to reduce particulate emission and enhance the cold flow properties of liquid transportation fuels [15]. Moreover, it decreases the gum formation, improves the oxidation stability, and the octane number when added to gasoline [14]. In addition, water in fuel storage tanks may cause problem due to the back hydrolysis to acetone and glycerol. Homogeneous catalysts, such as $\mathrm{H}_{2} \mathrm{SO}_{4}, \mathrm{HCl}, \mathrm{HF}$, and $p$-toluenesulphonic acid, can be applied for the ketalization of glycerol [16]. Although 
the homogeneously catalyzed processes give high conversion of glycerol, large amount of waste is produced during the separating and cleaning the catalyst. The use of heterogeneous catalysts has advantages to overcome the drawback. Hence, heterogeneous catalysts like Amberlyst-15 [17], Amberlyst-36 [18], montmorillonite K-10 [19], zeolites [17, 20], silica supported heteropoly catalysts [21], and mesoporous silicates containing arylsulfonate groups [22] are more favorable.

In this work, the influence of reaction conditions such as reaction time, catalyst amount, temperature and molar ratio of acetone to glycerol was investigated for the ketalization of glycerol to yield solketal over Amberlyst-46 catalyst. The reason of selection of Amberlyst-46 is its surface sulphonated structure which might provide easy accessibility of the acid sites and external adsorption and desorption during the reaction. Additionally, reusability of the catalyst was studied and EN 228 Standard- Automotive fuels - Unleaded petrol Requirements and test methods: research octane number (ISO 5164) and motor octane number (ISO 5163) applications were applied with oxygenated free gasoline blended with solketal.

\section{Materials and methods}

Glycerol and acetone (both $>99 \mathrm{wt} \%$ purity) were purchased from Merck. Solketal (1,2-isopropylideneglycerol, 97wt\%) was purchased from Sigma Aldrich to use in blends for MON and RON analysis and as calibration standard for GC analysis. The catalyst in solid form: Amberlyst-46 was procured from Dow Chemical. The properties of Amberlyst-46 were presented in Table 1.

Table 1 Properties of Amberlyst-46 catalyst.

\begin{tabular}{lllll}
\hline Matrix \& Type & Description & $\begin{array}{l}\text { Surface } \\
\text { area }\end{array}$ & $\begin{array}{l}\text { Temp. } \\
\text { limit }\end{array}$ & $\begin{array}{l}\text { Moisture } \\
\text { content }\end{array}$ \\
\hline & $\begin{array}{l}\text { Sulfonated } \\
\text { divinylbenzene } / \\
\text { styrene }\end{array}$ & $75 \mathrm{~m}^{2} / \mathrm{g}$ & $120^{\circ} \mathrm{C}$ & $26-36 \%$ \\
Macroreticular & & & \\
\hline Strong acid & copolymer & & & \\
\hline
\end{tabular}

The condensation of glycerol ( $5 \mathrm{~g}, 0.054 \mathrm{~mol})$ with acetone by using 6:1 acetone/ glycerol molar ratio over heterogeneous acid catalyst Amberlyst-46 of different \% (w/w) ratios was carried out through reflux in a $250 \mathrm{~mL}$ three-necked round bottom flask in an oil bath using condenser and a magnetic stirrer under inert $\left(\mathrm{N}_{2}\right)$ atmosphere. The reaction temperature was controlled with an external thermostat equipped with an external thermocouple with $0.1^{\circ} \mathrm{C}$ accuracy immersed in reaction mixture. The stirring speed was set to $500 \mathrm{rpm}$ in all experiments.

Product mixture was analyzed with a gas chromatograph, equipped with a mass spectrometer detector [Agilent $5975 \mathrm{C}$ GC/MS (EI), Agilent 7890 A GC equipped with capillary column $(30 \mathrm{~m} \times 0.25 \mathrm{~mm}$ ID $\times 0.25 \mu \mathrm{m}$ film)]. As a carrier gas helium was used with a flow rate of $1.2 \mathrm{~mL} / \mathrm{min}$. Oven temperature was adjusted at $450{ }^{\circ} \mathrm{C}$. NIST and WILEY library provided to name the components in the mixture. Product formation as means of solketal yield was calculated after calibration by using GC-FID (Agilent $6890 \mathrm{~N}$ ) under the conditions of pressure: $80 \mathrm{kPa}$, flow: $4.4 \mathrm{~mL} / \mathrm{min}$, oven: $80^{\circ} \mathrm{C} / 250^{\circ} \mathrm{C}$.

Solketal was mixed in 3, 5, 7 and $10 \mathrm{vol} \%$ with oxygenatefree gasoline. The corresponding blend was subjected to an analysis of EN 228 Standard- Automotive fuels - Unleaded petrol - Requirements and test methods: research octane number (ISO 5164) and motor octane number (ISO 5163) [23, 24]. The results were compared to the unblended gasolines. All experiments and analyses were repeated three times and average values were used.

\section{Results and Discussion \\ 3.1 Solketal synthesis}

Condensation of glycerol with acetone over Amberlyst-46 catalyst provided to reach the target compound. In order to determine the optimum reaction conditions, time of reaction, catalyst amount, temperature, acetone/glycerol mol ratio were studied. As shown in Fig. 1 the optimal reaction time was reached at 30 minutes and it was observed that the solketal yield remained stable at following times. The solketal yield and glycerol conversion reached to $84 \%$ at $30 \mathrm{~min}$ and remained almost constant (between $84 \%$ and $85 \%$ ) up to $300 \mathrm{~min}$.

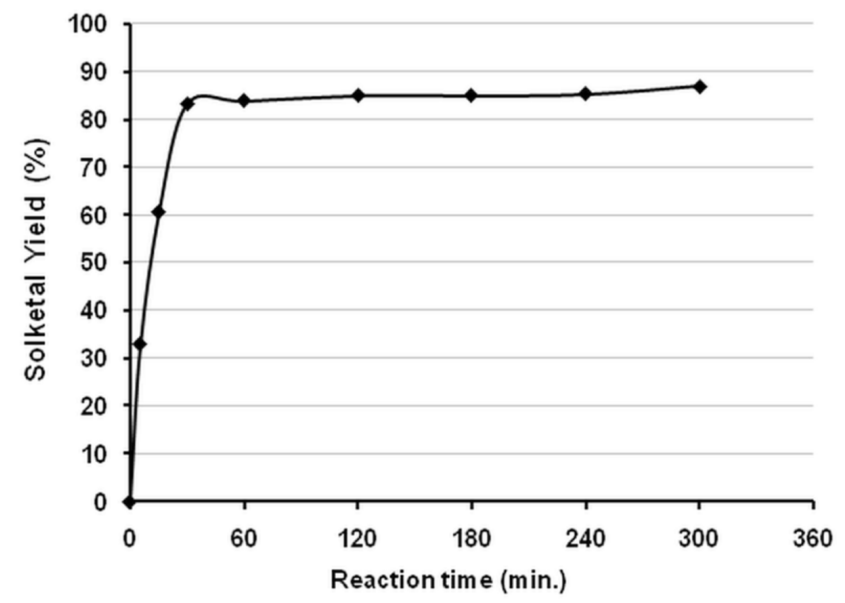

Fig. 1 Influence of reaction time on the yield of solketal (Reaction conditions: acetone/glycerol molar ratio, 6:1; catalyst amount, 1 wt. $\%$; temperature, $60{ }^{\circ} \mathrm{C}$ ).

Furthermore, the effect of catalyst dosage on solketal yield was investigated by varying the Amberlyst-46 loading from $0.5 \%(\mathrm{w} / \mathrm{w})$ to $5 \%(\mathrm{w} / \mathrm{w})$ while the other reaction parameters kept as constant (See Fig. 2). In absence of the catalyst no solketal formation was observed. Solketal yields were increased significantly and reached to $59 \%$ and $84 \%$ in the presence of $0.5 \%(\mathrm{w} / \mathrm{w})$ and $1 \%(\mathrm{w} / \mathrm{w})$ of catalyst amounts. Increase in the solketal yield can be explained by the increase in active sites of catalyst. Whereas, when the catalyst amount 
was further increased to $3 \%(\mathrm{w} / \mathrm{w})$ and $5 \%(\mathrm{w} / \mathrm{w})$, no further improvement was observed in the solketal yield. This was due to the reaction that had already reached equilibrium before the 30 min with the catalyst loadings higher than $1 \%(w / w)$. So, the catalyst amount of $1 \%$ was used in following experiments.

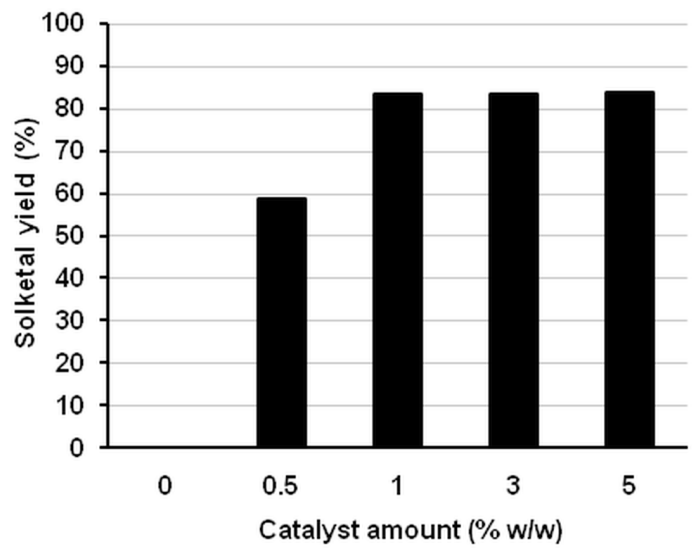

Fig. 2 Effect of catalyst amount on the yield of Solketal (Reaction conditions: acetone/glycerol molar ratio, 6:1; reaction time: $30 \mathrm{~min}$; temperature, $60{ }^{\circ} \mathrm{C}$ ).

The effect of reaction temperature was investigated at three different temperatures as shown in Fig. 3.

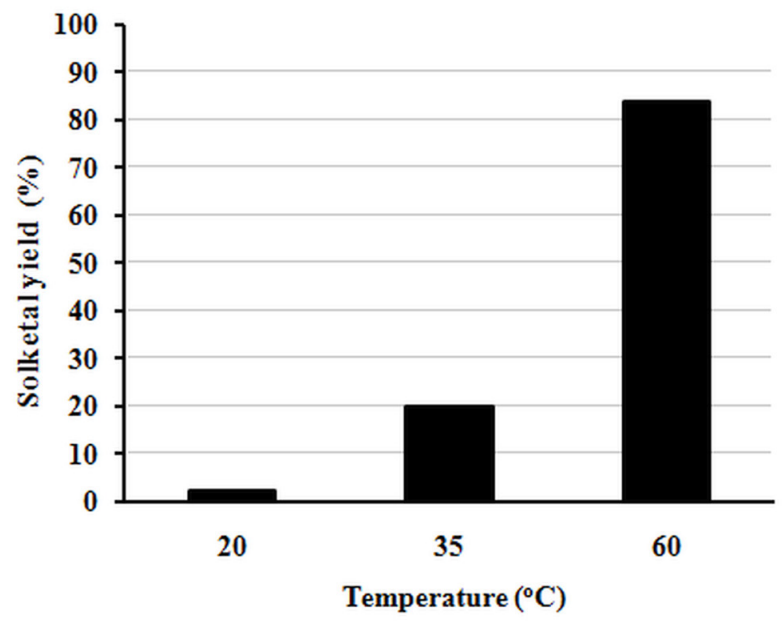

Fig. 3 Effect of reaction temperature on the yield of solketal (Reaction conditions: acetone/glycerol molar ratio, 6:1; catalyst amount, $1 \mathrm{wt} \%$; reaction time: $30 \mathrm{~min}$ ).

Comparatively lower solketal yields obtained at $20{ }^{\circ} \mathrm{C}$ and $35^{\circ} \mathrm{C}$, and a significant increase was observed at $60{ }^{\circ} \mathrm{C}$ of temperature. According to the study of Nanda et al. [25-26], thermodynamically higher reaction temperature results lower equilibrium yield since reaction is exothermic. Kinetically, the reaction rate increases with temperature while lower reaction temperature requires longer reaction time to reach equilibrium yield.

In this study, apart from 1:1 mol ratio of acetone/glycerol, three excess ratios of $3: 1,6: 1$ and 9:1 were investigated to see the effect of molar ratio. According to stoichiometry, more than one mole of acetone is necessary in order to improve the solketal yield. As shown in Fig. 4, by the use of $3: 1$ and $6: 1$ mol ratios, higher solketal yields were observed according to 1:1 mol ratio. On the other hand, for 9:1 mol ratio, the solketal yield remained as constant. The reason may be that the catalyst concentration decreased with increase of acetone content which increased the total volume.

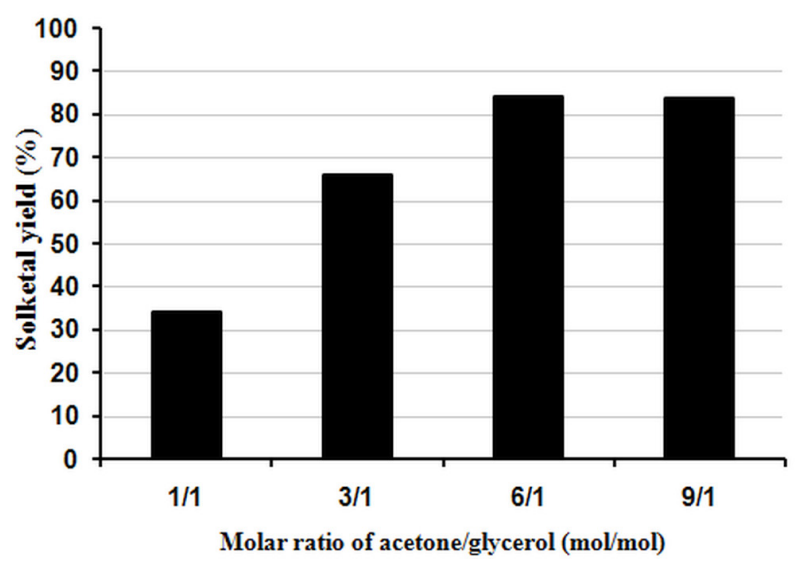

Fig. 4 Effect of acetone/glycerol molar ratio on the yield of solketal (Reaction conditions: catalyst amount, $1 \mathrm{wt}$ \% ; reaction time: $30 \mathrm{~min}$; temperature, $60{ }^{\circ} \mathrm{C}$ ).

\subsection{Reusability of the catalyst}

The reusability of the catalyst is really crucial to provide economic applicability of the solketal production process. In addition, it makes the process much more environmentally friendly than the homogeneous catalytic system, containing the simple separation from reaction mixture. In this study, for each following runs, the catalyst was separated by filtration and then reused after washing with acetone.

The reusable performance of the catalyst on solketal yield is shown in Fig. 5. As seen, after first cycle reused catalyst provided $68 \%$ the solketal yield which was $19 \%$ lower than the fresh catalyst and negligible decrease was observed for following cycles. The constant solketal yield of $62 \%$ was obtained after 7 th, 8 th and 9 th cycle of the reaction with same catalyst which was $26 \%$ lower than the fresh catalyst. The reason of drop may be due to the active site blockage by adsorbed by-products or feed contaminants which were not cleaned by washing process. It will be worth for further study for the regeneration of the catalyst.

\subsection{MON and RON analysis results of oxygenate free gasoline blended with solketal}

Octane is an important measure for gasoline quality. As respect to other parameters, octane serves to inform how well a vehicle will perform when fueled with such gasoline. Specifically, the octane rating measures a tendency of fuel to resist preignition in the combustion chamber [27].

In this work, the oxygenated compound solketal enhanced both MON and RON. It was blended 3, 5, 7 and $10 \%$ with oxygenate 
free gasoline by indicating good solubility. When compared blended ones according to the unblended gasoline, an increase in MON and RON were observed as shown in Figs. 6 and 7.

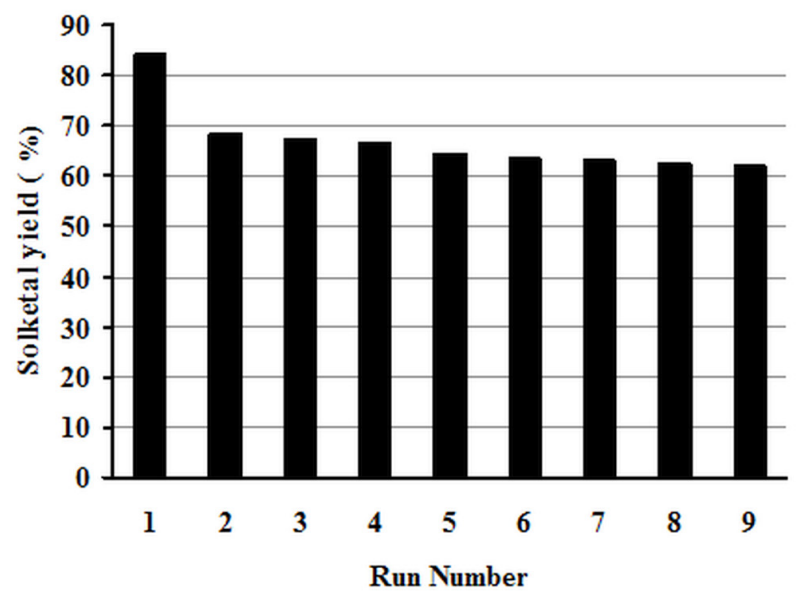

Fig. 5 Reusability of Amberlyst-46 catalyst for solketal synthesis (Reaction conditions: acetone/glycerol molar ratio, 6:1; catalyst amount, 1 wt. \%; reaction time: $30 \mathrm{~min}$; temperature, $60{ }^{\circ} \mathrm{C}$ ).

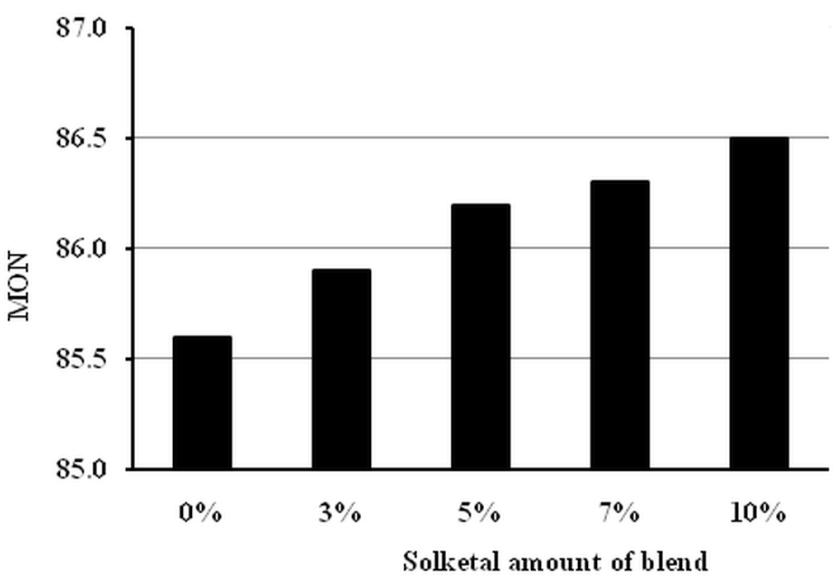

Fig. 6 Influence of solketal content on MON.

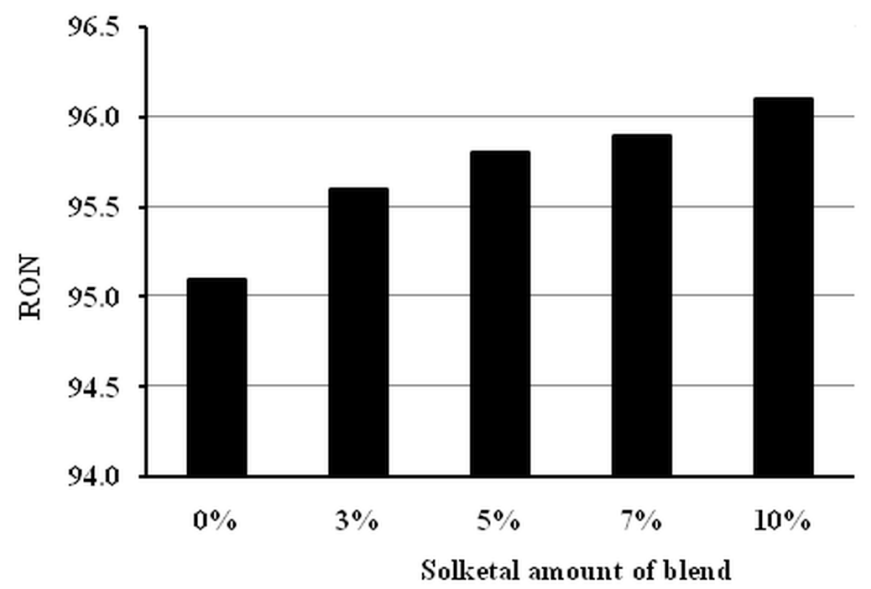

Fig. 7 Influence of solketal content on RON.

\section{Conclusions}

Conversion of glycerol with acetone over heterogeneous catalyst to solketal was optimized. Amberlyst-46 demonstrated effective performance to obtain required ketal. $84 \%$ yield was achieved under optimal reaction conditions as $\% 1(\mathrm{w} / \mathrm{w})$ catalyst, $60^{\circ} \mathrm{C}$ of temperature, 30 minute reaction time. Corresponding solketal was blended 3, 5, 7 and 10 vol\% with oxygenates free gasoline and subjected to $\mathrm{MON}$ and RON analysis according to ISO 5163 and ISO 5164 standards. Consequently, it was seen that the octane number of blends were improved as compared with unblended gasoline.

\section{Acknowledgement}

This study was supported by Kocaeli University through project BAP 2014/14.

\section{References}

[1] Ragauskas, A. J., Williams, C. K., Davison, B. H., Britovsek, G., Cairney, J., Eckert, Jr. Frederick, C. A., Hallett, J. P., Leak, D. J., Liotta, C. L., Mielenz, J. R., Murphy, R., Templer, R., Tschaplinski, T. "The path forward for biofuels and biomaterials." Science. 311(5760), pp. 484-489. 2006. https://doi.org/10.1126/science.1114736

[2] Lima, J. R. O., Ghani, Y. A., Silva, R. B., Batista, F. M. C., Bini, R. A., Varanda, L. C., Oliveira, J. E. "Strontium zirconate heterogeneous catalyst for biodiesel production: Synthesis, characterization and catalytic activity evaluation." Applied Catalysis A: General. 445, pp. 76-82. 2012. https://doi.org/10.1016/j.apcata.2012.08.005

[3] Giakoumis, E. G., Rakopoulos, C. D., Dimaratos, A. M., Rakopoulos, D. C. "Exhaust emissions with ethanol or n-butanol diesel fuel blends during transient operation: a review." Renewable and Sustainable Energy Reviews. 17, pp. 170-190. 2013. https://doi.org/10.1016/j.rser.2012.09.017

[4] Zhang, X., Wu, L., Zhang, R., Deng, S., Zhang, Y., Wu, J., Li., Y., Lin, L., Li, L., Wang, Y. Wang, L. "Evaluating the relationships among economic growth, energy consumption, air emissions and air environmental protection investment in China." Renewable and Sustainable Energy Reviews. 18, pp. 259-270. 2013. https://doi.org/10.1016/j.rser.2012.10.029

[5] Purushothaman, R. K. P., van Haveren, J., van Es, D. S., Melian-Cabrera, I., Heeres, H. J. "The oxidative esterification of glycerol to methyl glycerate in methanol using gold on oxidic supports: an insight in product selectivity." Green Chemistry. 14(7), pp. 2031-2037. 2012. https://doi.org/10.1039/C2GC35226E

[6] Meher, L. C., Sagar, D. V., Naik, S. N. "Technical aspects of biodiesel production by transesterification-a review." Renewable and Sustainable Energy Reviews. 10(3), pp. 248-268. 2006.

https://doi.org/10.1016/j.rser.2004.09.002

[7] Garcia, E., Laca, M., Pérez, E., Garrido, A., Peinado, J. "New class of acetal derived from glycerin as a biodiesel fuel component." Energy \& Fuels. 22(6), pp. 4274-4280. 2008. https://doi.org/10.1021/ef800477m

[8] OECD/FAO "OECD-FAO Agricultural Outlook 2011-2020." OECD Publishing. 2011. https://doi.org/10.1787/agr_outlook-2011-en

[9] Ang, G. T., Tan, K. T., Lee, K. T. "Recent development and economic analysis of glycerol-free processes via supercritical fluid transesterification for biodiesel production." Renewable and Sustainable Energy Reviews. 31, pp. 61-70. 2014. https://doi.org/10.1016/j.rser.2013.11.004 
[10] Chai, S. H., Wang, H. P., Liang, Y., Xu, B. Q. "Sustainable production of acrolein: gas-phase dehydration of glycerol over $\mathrm{Nb}_{2} \mathrm{O}_{5}$ catalyst." Journal of Catalysis. 250(2), pp. 342-349. 2007. https://doi.org/10.1016/j.jcat.2007.06.016

[11] Dasari, M. A., Kiatsimkul, P. P., Sutterlin, W. R., Suppes, G. J. "Lowpressure hydrogenolysis of glycerol to propylene glycol." Applied Catalysis A: General. 281(1), pp. 225-231. 2005. https://doi.org/10.1016/j.apcata.2004.11.033

[12] Klepáčová, K., Mravec, D., Bajus, M. "tert-Butylation of glycerol catalysed by ion-exchange resins." Applied Catalysis A: General. 294(2), pp. 141-147. 2005. https://doi.org/10.1016/j.apcata.2005.06.027

[13] Soares, R. R., Simonetti, D. A., Dumesic, J. A. "Glycerol as a source for fuels and chemicals by low temperature catalytic processing." Angewandte Chemie. 118(24), pp. 4086-4089. 2006. https://doi.org/10.1002/anie.200600212

[14] Mota, C. J., da Silva, C. X., Rosenbach Jr, N., Costa, J., da Silva, F. "Glycerin derivatives as fuel additives: The addition of glycerol/acetone ketal (solketal) in gasolines." Energy \& Fuels. 24(4), pp. 2733-2736. 2010. https://doi.org/10.1021/ef9015735

[15] Cablewski, T., Faux, A. F., Strauss, C. R. "Development and application of a continuous microwave reactor for organic synthesis." The Journal of Organic Chemistry. 59(12), pp. 3408-3412. 1994. https://doi.org/10.1021/j000091a033

[16] Krief, A., Provins, L., Froidbise, A. "Diastereoselective synthesis of dimethyl cyclopropane-1, 1-dicarboxylates from a $\gamma$-alkoxy-alkylidene malonate and sulfur and phosphorus ylides." Tetrahedron Letters. 39(11), pp. 1437-1440. 1998. https://doi.org/10.1016/S0040-4039(97)10822-X

[17] da Silva, C. X. A., Gonçalves, V. L. C., Mota, C. J.A. "Water-tolerant zeolite catalyst for the acetalisation of glycerol." Green Chemistry. 11(1), pp. 38-41. 2009. https://doi.org/10.1039/B813564A

[18] Deutsch, J., Martin, A., Lieske, H. "Investigations on heterogeneously catalysed condensations of glycerol to cyclic acetals." Journal of Catalysis. 245(2), pp. 428-435. 2007. https://doi.org/10.1016/j.jcat.2006.11.006
[19] Roldán, L., Mallada, R., Fraile, J. M., Mayoral, J. A., Menendez, M. "Glycerol upgrading by ketalization in a zeolite membrane reactor." Asia Pacific Journal of Chemical Engineering. 4(3), pp. 279-284. 2009. https://doi.org/10.1002/apj.243

[20] Maksimov, A. L., Nekhaev, A. I., Ramazanov, D. N., Arinicheva, Y. A., Dzyubenko, A. A., Khadzhiev, S. N. "Preparation of high-octane oxygenate fuel components from plant-derived polyols." Petroleum Chemistry. 51(1), pp. 61-69. 2011. https://doi.org/10.1134/S0965544111010117

[21] Ferreira, P., Fonseca, I. M., Ramos, A. M., Vital, J., Castanheiro, J. E. "Valorisation of glycerol by condensation with acetone over silica-included heteropolyacids." Applied Catalysis B: Environmental. 98(1), pp. 94-99. 2010. https://doi.org/10.1016/j.apcatb.2010.05.018

[22] Vicente, G., Melero, J. A., Morales, G., Paniagua, M., Martín, E. "Acetalisation of bio-glycerol with acetone to produce solketal over sulfonic mesostructured silicas." Green Chemistry. 12(5), pp. 899-907. 2010. https://doi.org/10.1039/B923681C

[23] Kyriakides, A., Dimas, V., Lymperopoulou, E., Karonis, D., Lois, E. "Evaluation of gasoline-ethanol-water ternary mixtures used as a fuel for an Otto engine." Fuel. 108, pp. 208-215. 2013. https://doi.org/10.1016/j.fuel.2013.02.035

[24] Knuuttila, P. "Wood sulphate turpentine as a gasoline bio-component." Fuel. 104, pp. 101-108. 2013. https://doi.org/10.1016/j.fuel.2012.06.036

[25] Nanda, M. R., Yuan, Z., Qin, W., Ghaziaskar, H. S., Poirier, M. A., Xu, C. C. "Thermodynamic and kinetic studies of a catalytic process to convert glycerol into solketal as an oxygenated fuel additive." Fuel. 117, pp. 470477. 2014. https://doi.org/10.1016/j.fuel.2013.09.066

[26] Nanda, M. R., Yuan, Z., Qin, W., Ghaziaskar, H. S., Poirier, M. A., Xu, C. C. "A new continuous-flow process for catalytic conversion of glycerol to oxygenated fuel additive: Catalyst screening." Applied Energy. 123 , pp. 75-81. 2014. https://doi.org/10.1016/j.apenergy.2014.02.055

[27] Zhou, Y., Song, J., Liang, S., Hu, S., Liu, H., Jiang, T., Han, B. "Metalorganic frameworks as an acid catalyst for the synthesis of ethyl methyl carbonate via transesterification." Journal of Molecular Catalysis A: Chemical. 308(1), pp. 68-72. 2009. https://doi.org/10.1016/j.molcata.2009.03.027 